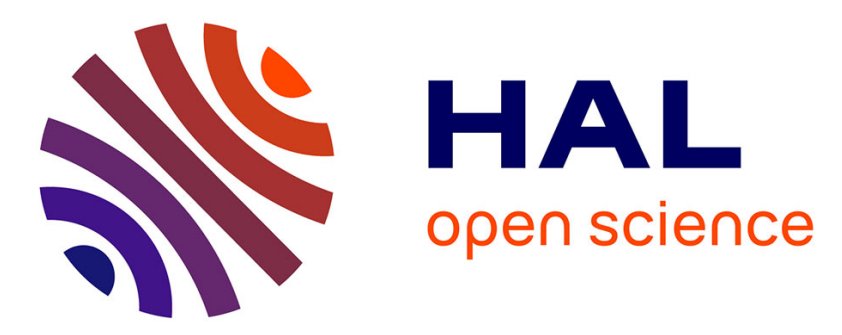

\title{
Internet Governance and the Reshaping of Global Human Rights Legacy at WSIS+10
}

Rikke Frank Joergensen, Meryem Marzouki

\section{To cite this version:}

Rikke Frank Joergensen, Meryem Marzouki. Internet Governance and the Reshaping of Global Human Rights Legacy at WSIS+10. 10th GigaNet Annual Symposium, Nov 2015, João Pessoa, Brazil. http://giga-net.org/page/2015-annual-symposium. hal-01297008

\section{HAL Id: hal-01297008 \\ https://hal.science/hal-01297008}

Submitted on 1 Apr 2016

HAL is a multi-disciplinary open access archive for the deposit and dissemination of scientific research documents, whether they are published or not. The documents may come from teaching and research institutions in France or abroad, or from public or private research centers.
L'archive ouverte pluridisciplinaire $\mathbf{H A L}$, est destinée au dépôt et à la diffusion de documents scientifiques de niveau recherche, publiés ou non, émanant des établissements d'enseignement et de recherche français ou étrangers, des laboratoires publics ou privés.

\section{(ㅇ)(1) $\$$}

Distributed under a Creative Commons Attribution - NonCommercial - NoDerivatives $\mid 4.0$ 
Suggested citation: Rikke Frank Joergensen, Meryem Marzouki. Internet Governance and the Reshaping of Global Human Rights Legacy at WSIS+10. 10th GigaNet Annual Symposium, Nov 2015, João Pessoa, Brazil. <http://giga-net.org/page/2015-annual-symposium>. <hal-01297008>

\title{
Internet Governance and the Reshaping of Global Human Rights Legacy at WSIS+10
}

\author{
Paper Prepared for the 10th GigaNet Annual Symposium \\ 9 November 2015 - João Pessoa, Brazil
}

Rikke Frank Jørgensen (Danish Institute for Human Rights, Copenhagen,
Denmark)
Meryem Marzouki (CNRS and UPMC Sorbonne Universités, Paris, France)

\section{Introduction}

International policy discourses related to the digital environment increasingly reference human rights and fundamental freedoms. From the early debates in the mid-1990s on the human rights implications of internet use, to the new momentum created by Edward Snowden's revelations of State surveillance in 2013, the issue has received considerable attention over the past 20 years.

At the global and regional levels, a historical perspective identifies several milestones in this global evolution. To name a few of these milestones: the early WSIS steps (2002-2005), with the "Right to Communicate" vision opposed to one that promoted the identification of practical ways to realize and advance existing human rights in the online environment, with a special emphasis on the indivisibility and interdependence of all human rights; the IGF steps (2006-present), with different stakeholders, on their own or through multi-stakeholder dialogues, working on various initiatives aimed at strengthening the human rights perspective in internet policy; the UN Human Rights Council (HRC) and Universal Periodic Review (UPR) proceedings where, since 2012, global NGO coalitions specializing in human rights on the internet closely cooperated with the (former) UN Special Rapporteur on Freedom of Expression who was very attentive towards internet-related issues and the need to address internet policy from a human rights perspective. These efforts, together with some government led actions dedicated to freedom of expression and privacy in particular, have resulted in the adoption of the first two Resolutions focusing specifically on human rights protection on the internet, adopted at the UN 
Human Rights Council in $2012^{1}$ and $2014^{2}$, as well as the first two Resolutions on Privacy in the Digital Age, adopted at the UN General Assembly in $2013^{3}$ and $2014^{4}$.

In parallel, the usual process of national and regional (e.g. in the European Union) internet policy making has been going on through legislation, jurisprudence and regulation, often independently of the global discussions and sometimes even detached from the concern raised by some Europeans governments and other institutions in global governance arenas. Likewise, civil society groups and other actors have pursued (sometimes in coordinated efforts) the call for the protection and enforcement of human rights standards in the online domain through advocacy, lobbying, and campaigning, locally as well as regionally.

Finally, the emergence of internet giants with the advent of web2.0 and social networking applications and services has raised the fundamental challenge that the conditions for public and private life on the internet depend on infrastructure and platforms governed by the private companies that provide them. In addition to the daily use of such platforms for a major part of our activities, activists' use of social media to organize and publicize their actions to fight authoritarian regimes and/or socio-economic inequalities, have proven to be a common feature among otherwise very different cultural backgrounds, political contexts and associated issues.

There is by now common agreement that human rights apply online as they do offline, yet in practice the modalities of the online realm provide significant challenges to human rights protection, many of which remain

\footnotetext{
${ }^{1}$ See United Nations, Human Rights Council, resolution 20/8, The promotion, protection and enjoyment of human rights on the internet, A/HRC/RES/20/8 (16 July 2012), available from http://www.un.org/ga/search/view_doc.asp?symbol=A\%2FHRC\%2FRES\%2F20\%2F8\& Submit=Search\&Lang=E

2 See United Nations, Human Rights Council, resolution 26/13, The promotion, protection and enjoyment of human rights on the internet, A/HRC/RES/26/13 (14 July 2014), available from http://daccess-ddsny.un.org/doc/UNDOC/GEN/G14/082/83/PDF/G1408283.pdf?OpenElement ${ }^{3}$ General Assembly, resolution 68/167, The right to privacy in the digital age, A/RES/68/167 (21 January 2014, adopted by the General Assembly on 18 December 2013), available from http://www.un.org/en/ga/search/view_doc.asp?symbol=A/RES/68/167 ${ }^{4}$ See General Assembly resolution 69/166, The right to privacy in the digital age, A/RES/69/166 (10 February 2015, adopted by the General Assembly on 18 December 2014), available at http://www.un.org/en/ga/search/view_doc.asp?symbol=A/RES/69/166
} 
largely unexplored. Moreover, in the course of the above-mentioned efforts, new "digital rights" have been suggested and advocated by different groups and coalitions, such as the "right to internet access" seen as a necessary precondition to democratic participation; the "right to be forgotten" in the field of privacy and personal data protection.

Focusing on these proposed new "digital rights", the authors explore in this paper the background of such proposals and how they have unfolded over time and across various arenas and circumstances. The paper analyzes how different actors (states, intergovernmental organizations, civil society, technical community, internet companies) have been framing and advancing these proposals through either political contention or coalition of interests around key international events and momentum, paying particular attention to the role and influence of WSIS and post-WSIS multistakeholder internet governance processes. In conclusion, the authors discuss the broader human rights implications of this development, arguing (1) that it reflects the strong impact of the specifics of the online environment on the very concept of fundamental rights, and (2) may constitute threats to the universality and indivisibility of all human rights, and undermine the level of human rights protection online.

\section{Human Rights and Communication Rights: An everlasting controversy?}

"We [...] declare our commitment to a common goal of building a people's internet from below and beyond borders: an internet that works in the public interest and solidarity, where control is in the hands of people; an internet based on human dignity, equality, social justice, freedom and people's communication rights".

This sentence opens the "Tunis Resolution" ${ }^{5}$ ", adopted by the participants of the Workshop "Organizing an internet Social Forum - A Call to Occupy the internet", held in Tunis as part of the World Social Forum 2015. It is the most recent reference to date to the concept of 'Communication Rights' in an adopted document that, interestingly enough, does not make a single reference to 'Human Rights' as the existing international normative framework defined by the United Nations Bill of Rights (though it was indeed mentioned in the initial 'Call For An internet Social Forum' ${ }^{6}$, which led to the organization of this first workshop as a first step towards the internet Social Forum.

\footnotetext{
${ }^{5}$ See http://internetsocialforum.net/isf/?page_id=832

${ }^{6}$ See http://internetsocialforum.net/isf/?page_id=848
} 
Moreover, the Workshop that led to the adoption of this 'Tunis Resolution' was mainly an initiative of the JustNet Coalition (JNC), one of the civil society coalitions active in IGF and most recent related internet governance initiatives ${ }^{7}$. Indeed, all $35 \mathrm{JNC}$ organizational members are signatories of the Call, and constitute half of the overall signatories; furthermore, four of the indicated regional contacts are representatives of JNC organizational members, while the fifth is one of JNC individual members. When looking at JNC organizational members, the insider of WSIS and post-WSIS activities can easily identify some of the most prominent members of the 'Communication Rights in the Information Society' (CRIS) Campaign that played a major role during early WSIS steps, until the end of WSIS first phase in 2003 (CRIS, 2005).

Put together, both the framing of the 'Tunis Resolution' text and the identification of major players in the announced internet Social Forum ring a bell, reminding the main controversy related to human rights within civil society during WSIS first phase, that we identified and analyzed at that time (Marzouki and Jørgensen, 2004; Jørgensen and Marzouki, 2005). When adding the continuous confrontation ${ }^{8}$ of internet governance visions between (members of) the JNC and BestBits ${ }^{9}$, another main civil society coalition active in the same post-WSIS circles, it becomes clear that we might soon observe a remake, ten or fifteen years later, of the same old controversy.

The description and analysis of various civil society components and their agonistic as well as antagonistic - interactions in post-WSIS developments being beyond the scope and objective of this paper, we will only mention here some of their specific positions on one issue or another when relevant. However, the controversy related to human rights needs to be elaborated upon when analyzing internet governance and the reshaping of global human rights legacy.

\footnotetext{
${ }^{7}$ Founded in February 2014, the JNC introduces itself on its website as "a global network of civil society actors committed to an open, free, just and equitable internet". See http://justnetcoalition.org/.

${ }^{8}$ As their exchanges on internet governance mailing lists (including their own ones) attest.

${ }^{9}$ The Bestbits coalition describes itself as "an inclusive network of key civil society organizations from across the world, who come together to highlight their various initiatives, and foster mutual learning and broader engagement", see http://bestbits.net/organizer/best-bits/. It started its activities in 2012.
} 
This controversy finds its roots back in the late 1960s, with the proposal of a right to communicate. The right was first suggested by Jean d'Arcy - a pioneer in French and European television - in an attempt to link human rights with recent (at that time) developments in communication technology, in particular satellite communication. Although a precise definition of the right to communicate was never provided, the basic idea was that Article 19 of the UDHR was too narrow to encompass the implications of technological developments, and that the right to communicate should encompass more extensive possibilities, so that electronic communication would no longer be confined to the media elite.

Further attempts to define the right to communicate and its practical implementation, most notably in terms of satellite spectrum regulation, led to heated debates at the UNESCO in the mid-70s, with the attempt to promote a so-called "New World Information and Communication Order" (NWICO) (CRIS, 2005: Chapter 2; McKenna, 2011: Chapter 6; Frau-Meigs et al., 2012). At end of this controversy, supporters of the right to communicate were opposed to defenders of the "free flow of information" doctrine, and it finally ended with ideological clashes between the East and the West (that was during the cold war) and between the North and the South (with the Non Aligned Movement, in particular). When the McBride Commission released its report ("Many Voices, One World") in 1980, attempting to define the conditions for realizing a right to communicate, unresolved ideological differences led the US and the UK to withdraw from UNESCO.

With the early steps of the World Summit on the Information Society (WSIS) came a resurgence of the right to communicate, this time at the initiative of the "Communication Rights in the Information Society" (CRIS) Campaign. The CRIS campaign proposed the idea of a right to communicate in response to, among others, concerns about media concentration to the civil society plenary formed around WSIS, aiming for general support by civil society. Like in the old NWICO conflict, the idea was opposed in the name of the free flow of information, this time by the Media Caucus. It also faced contradiction from the Human Rights Caucus. The Human Rights Caucus shared the concerns raised by the CRIS campaign, yet disagreed on the means to resolve them. Rather than introducing new human rights, the Human Rights Caucus iterated the need to translate existing human rights to the digital environment, and to identify practical ways of realizing and advancing them, with emphasis on the indivisibility and interdependence of all human rights. 
The debate within civil society on this issue at WSIS was resolved by the end of the first WSIS phase. At the "World Forum on Communication Rights ${ }^{10 "}$, it was agreed that the call for the effective enjoyment of a right to communicate needs not invent new legal standards, but should rather concert in the call for enforcement of existing human rights standards. This shift was explicitly acknowledged by the CRIS Campaign: "the use of the term "communication rights", since it is in the plural form, implicitly points towards existing human rights that relate to communication, and away from promoting a new formal right to communicate, in the singular, in international law. The emphasis shifts subtly to realizing the existing communication rights on the ground, not on establishing a new right under international law" (CRIS, 2005: p. 19).

Another controversy within civil society we highlighted ten years ago was the linkage between human rights and development (Jørgensen and Marzouki, 2005). During WSIS, a number of organizations claimed that the issue of development (poverty reduction and economic and social development) was to take priority over human rights, especially in joint civil society documents. This perspective presupposes a distinction between development and human rights, rather than recognizing that the two are intimately related as was time and again stressed at the Vienna World Conference on Human Rights in 1993. The debate is a reminder of the fact that a number of civil society organizations do not see human rights as the normative foundation for any society, independent on the level of development, but rather as something secondary to issues of development. On the other hand, many civil society organizations, specially from northern countries, show a rather restricted understanding of human rights, in that they may only consider, among the whole set of human rights, civil and political rights. Unlike the discussions around the right to communicate, this contradiction within civil society was not resolved by the end of WSIS.

Although these two main controversies have largely evolved since then (Padovani et al., 2010; Jørgensen, 2013), especially through their reframing and reshaping taking into account the evolution of the technology and the economy, as well as other global transformations, they are still underpinning most of internet governance visions and debates, including the most recent ones. One of the strongest sign of their persistence is the foundation of the JustNet Coalition in 2014, as both a specific political stand and a detachment move from the BestBits coalition claims, notwithstanding

10 The Forum was co-organized by, among others, the CRIS campaign and the Human Rights Caucus as a side event to the WSIS Summit in Geneva in 2003. See the web site at: http://www.communicationrights.org/ 
BestBits' claim since its creation in 2012 to "not aim to present a single solution for ratification by the assembled groups, but rather to offer an open space where each group can present and advocate for the initiatives that they believe offer the best positive agenda for advancing broadly shared civil society interests in internet governance ${ }^{11 "}$. There is no doubt that the internet Social Forum, expected to be held early 2016, will confirm the divergences. In the mean time, these controversies kept flourishing through debates on specific issues, such as the "right to internet access", suggested and advocated by different groups and coalitions as a new "digital right".

\section{internet Access: A Right In Its Own?}

In parallel to the WSIS debate on a right to communicate (which mainly took place amongst civil society actors), was a related but less politicized debate on internet access. In the early years of this debate, it mainly referred to technology infrastructure and the fact that the majority of the world population remain without such access, often referred to as the "the digital divide" although this is a highly contested notion, especially as it is trying to find technological solutions to problems that are essentially socioeconomic (Parayil, 2005; Pieterse, 2006; Wildermuth, 2010). Interestingly, in a context where the main economic actors were not anymore the major media corporations but rather the big internet intermediaries, this debate around internet access was framed differently from the right to communicate.

Most notably, it had a more narrow and technical perspective on internet access, addressing it primarily as a matter of infrastructure (or lack hereof). This is not surprising since one of the main UN bodies dealing with WSIS was the ITU (tasked with telecommunication infrastructure), and since many government delegates struggled to make sense of the exact content of the information society Summit. Dealing with obvious inequalities in access to infrastructure including how to "roll out" more infrastructure was a concrete and less controversial topic than the socio-economic dynamics underlying these global differences. To put this into figures, as of 2014, of approximately 3 billion users, an estimated 78 percent reside in developed countries with great variations across regions. While Europe has an internet penetration rate of over 75 percent, less than one-fifth of African households are connected ${ }^{12}$. Although the developing countries have increased their internet penetration growth rate, they still represent 90

\footnotetext{
${ }^{11}$ See supra note 9

${ }^{12}$ See http://www.un.org/apps/news/story.asp?NewsID=47729\#.VdM40lyTKI1
} 
percent of the 4 billion people not yet connected to the internet ${ }^{13}$. The lack of internet access for a majority of the world's population has since WSIS spurred a number of intergovernmental initiatives such as the International Telecommunications Union's 'Connect the World' initiative that seeks to provide access to ICT to some one billion people living in remote areas by $2015^{14}$. Moreover, it continues to be on the agenda of every internet Governance Forum. It is, however, increasingly addressed as a broader theme, paying attention to the many factors that enable participation in the digital domain.

More recently, this debate has developed into proposals for a human right to internet access. The definition of such a new right is rather fuzzy, and not well defined - neither in concept nor scope. Global civil society networks such as the Association for Progressive Communication (APC) had started to frame internet access as a human right in their work on internet rights during the WSIS process, producing in 2006 the "APC internet Rights Charter ${ }^{15}$ ". The document's name itself is worth noting: during WSIS where APC played a leading role in organizing civil society activities, the APC - a global network of organizations - was a member of both the CRIS Campaign and of the Human Rights Caucus. As such, the APC was well aware of the human rights vs. the right to communicate / communication rights controversy. The framing of its work related to rights in the online environment as "internet rights" allowed it to move on from this recurring debate. Yet, the need to incorporate the specifics of APC's vision and concern led the organization to keep a free hand with the international human rights framework, rather than strictly translating this framework in the online environment. As a matter of fact, the 2006 APC Charter claims not only for a "right to access", but for some even more unexpected "rights", such as "the right to open architecture", or "the right to the internet as an integrated whole". These proposed "rights" are neither precisely defined in the 2006 Charter, nor is it explained how they derive from international human rights standards. Although they are added to some of the established human rights, it becomes understandable why the framing of "internet rights" - rather than human rights - was preferred for this collection of claims, wishes or principles.

This initial work was further elaborated in the process of developing the

\footnotetext{
${ }^{13}$ See http://www.itu.int/en/ITU-D/Statistics/Documents/facts/ICTFactsFigures2014e.pdf

${ }^{14}$ See the International Telecommunication Union, Connect the World, available at: www.itu.int/ITU-D/connect

${ }^{15}$ See https://www.apc.org/en/node/5677/
} 
first version of the "IRPC Charter of Human Rights and Principles on the internet ${ }^{16 "}$. The Charter was developed from 2009 onwards by the internet Rights and Principles Coalition (IRPC), a multi-stakeholder coalition formed at the IGF (Franklin, 2013: Chapter 5). Its first version was released by end 2010. The chosen approach, as recommended by the group of human rights experts having provided the first $\mathrm{draft}^{17}$, was to start from the UDHR, and to keep as close as possible to its defined rights and other provisions (only some obviously irrelevant in the context, such as that of Article 16 for instance, were not included). The Charter stresses the transformative nature of the internet not only to enable individuals to exercise their right to freedom of expression, but also to enjoy a range of other human rights, including the right to health, the right to education, the right to gender equality and so forth. It also goes beyond the rights stipulated in the international Bill of human rights, to incorporate, for instance, provisions on the right to development. The IRPC Charter does stipulate in its Article 1 a "Right to access the internet". However, its provisions make it clear how it is intended: "access to and use of the internet is increasingly indispensible for the full enjoyment of human rights, including [main UDHR rights listed]. Moreover, and as a parallel to the above comment on APC Charter's name, the IRPC Charter is that of "Rights and Principles on the internet" (italics is ours): not only does this clearly express the chosen approach of translating established (human) rights into the online environment, but also, when additions are made, they should be considered as "principles" rather than rights. This particularly applies when the Charter refers to the internet technical design principles to express the importance of not altering them in order to realize some of the human rights. As a matter of fact, the Charter comes with some explanatory statements, one of them being "What do we mean by human rights and principles?".

In 2011, the debate on internet access as a human right was fueled by a number of media outlets that mistakenly claimed that Frank La Rue (at the time UN Special Rapporteur on the promotion and protection of the right to freedom of opinion and expression) had declared such a right. In fact, what La Rue had recommended was to make universal internet access a priority for all states ${ }^{18}$. The rapporteur appreciated that this could not be instantly

\footnotetext{
${ }^{16}$ See http://internetrightsandprinciples.org/site/charter/

17 Especially since some of them directed or contributed to a previous effort of translating human rights into the information society context (Jørgensen, 2006)

18 See Paragraph 86 of Report of the Special Rapporteur on the promotion and protection of the right to freedom of opinion and expression, Frank La Rue, A/HRC/17/27 (16 May 2012). Available at:

http://www2.ohchr.org/english/bodies/hrcouncil/docs/17session/A.HRC.17.27_en.pdf
} 
achieved because of, for example, deficient electricity access ${ }^{19}$. Nevertheless, States are positively obliged to promote or enable the means necessary for individuals to exercise their freedom of expression. Also, once the infrastructure has been established, policies and strategies should be adopted which make the internet widely available, accessible and affordable for all. Similarly, the first UN "Resolution on the promotion, protection and enjoyment of human rights on the internet" adopted in July $2012^{20}$ does not recognize a right to internet access. Nor does it prescribe any universal service provision, or suggest revising existing peering and transit agreements in order to make internet access universally affordable. The resolution does, however, stress the freedom to access the internet and includes a "call upon all States to promote and facilitate access to the internet and international cooperation aimed at the development of media and information and communication facilities in all countries". Likewise, the UN Human Rights Committee in its general comment on freedom of expression considers that internet-based modes of expression are protected and that States should accordingly adopt all necessary steps to ensure access to the internet ${ }^{21}$.

Actually several countries - especially within Europe - have already stipulated universal internet access in national legislation ${ }^{22}$. The EU Universal Service Directive amended in 2009 (2009/136/EC) stresses that everyone within the EU must be able to access a minimum set of electronic communication services of good quality and at an affordable price. Also, all reasonable requests for connection at a fixed location to a public communication network must be met by at least one operator ${ }^{23}$.

In a highly debated newspaper article from January 2012, Vincent Cerf - a key figure in the technical community around internet governance - argued against a human right to access the internet. Cerf's main concern is that

${ }^{19}$ Ibid. Paragraph 66

${ }^{20}$ UNGA Resolution A/HRC/20/L.13, adopted in June 2012. Available at:

http://daccess-dds-ny.un.org/doc/UNDOC/LTD/G12/147/10/PDF/G1214710.pdf

21 See Un Human Rights Committee General Comment No. 34 on Article 19: Freedoms of opinion and expression. Available at :

http://www2.ohchr.org/english/bodies/hrc/docs/gc34.pdf

22 Examples include the Estonian Telecommunication Act (2000), a ruling by the French Constitutional Court (2009), Amendment to the Finish Communication Market Act (2010), a ruling by the Costa Rican Constitutional Court (2010), and an amendment to the Spanish Act on sustainable economy (2011). For further details please refer to Pollicino and Bassini (2011: 29)

${ }^{23}$ See section 1 of the Code of EU Online Rights, which is based on the Universal Service Directive 
technology is an enabler, not a right in itself: "There is a high bar for something to be considered a human right. Loosely put, it must be among the things we as humans need in order to lead healthy, meaningful lives, like freedom for torture or freedom of conscience. It is a mistake to place any technology in this exalted category 24 ". In response, proponents of this new right argued that access to the internet is a precondition for enjoying a number of other human rights and should therefore be considered a right on its own merits ${ }^{25}$. In line with this, a BBC survey amongst 27000 people in 26 different countries in 2010 showed that four out of five believed internet access to be a basic human right ${ }^{26}$.

Most recently, the Council of Europe's Parliamentary Assembly have adopted a resolution on the right to internet access. The resolution stresses the need for universal service requirements on internet access throughout Europe and beyond, and iterates that everyone shall have the right to internet access as an essential requirement for exercising rights under the European Convention on Human Rights. In consequence, "States should recognize the fundamental right to internet access in law and in practice"27. On a more cautious note (and practically at the same time), the Council of Europe's Committee of Ministers has adopted a Recommendation on a Guide for Human Rights of internet users ${ }^{28}$. The Guide itself heavily relies on the above-mentioned IPRC Charter (the Council of Europe has been a member of the multi-stakeholder IRPC coalition; and the committee of experts that was set up to draft the Recommendation, including the Guide as its Annex, included several IRPC members that were involved in developing the Charter). The Guide thus translates existing human rights standards to the online environment, and provides important guidance as to how the European human rights system assesses the scope of each right. Concerning access to the internet, this is addressed in the first section of the Guide (together with the principle of non discrimination), but not as a right in its own merit. As stated in the presentation to the Guide: "The guide does not establish new human rights and fundamental freedoms. It builds on existing human rights standards and enforcement mechanisms". This formulation derives from the terms of references for the committee of

\footnotetext{
24 This Op-Ed published by Vint Cerf in the New York Times on 4 January 2012 is available at: http://www.nytimes.com/2012/01/05/opinion/internet-access-is-not-ahuman-right.html

25 See blog post from Amnesty International USA of 10 June 2012. Available at : http://blog.amnestyusa.org/middle-east/is-internet-access-a-human-right/

${ }^{26}$ See http://news.bbc.co.uk/2/hi/technology/8548190.stm

27 Resolution 1987 on The Right to internet Access (2014) is available at: http://assembly.coe.int/nw/xml/XRef/X2H-Xref-ViewPDF.asp?FileID=20870 ${ }^{28}$ See http://www.coe.int/en/web/internet-users-rights/guide
} 
experts set up to develop the Guide, and was a requirement from the Council of Europe member states: contrarily to the Parliamentary Assembly, member states did not want to engage in the politically sensitive process of defining new human rights, especially in an instrument carrying a higher level of commitment than a Resolution.

A final example of developments around internet access relates to industrydriven initiatives such as Facebook's internet.org project that aims "to connect the two third's of the world that doesn't have internet access"29. The initiative is a partnership between the social media platform and a number of ICT companies such as Nokia, Ericsson and Samsung, and provides users with a Facebook-defined internet platform. When presenting the project, Facebook founder Mark Zuckerberg asserted ${ }^{30}$ : "connectivity is a human right". Since its launch in 2013, the initiative has been criticized by civil society (not least in India and Brazil) for violating net neutrality and for Facebook's role as gatekeeper in determining what websites users of internet.org may access. In particular, a number of NGOs sent an open letter ${ }^{31}$ to Facebook to express their opinion on this initiative. As one of the signatory organizations commented, they considered that "internet.org comes with too many strings attached ${ }^{22}$ ". Following these critiques, Facebook rebranded ${ }^{33}$ its initiative in September 2015 into "Free Basics", and added some new services to it. On a related note is Google's Loon project ${ }^{34}$ that was launched in 2013 with the aim of providing internet access to rural and remote areas. The project uses high-altitude balloons to create an aerial wireless network, and have users connect to the network via a special antenna attached to their building. Unlike internet.org, the project has so far been well received.

In sum, while a right to internet access has been widely promoted and debated, it seems fair to conclude that a (positive) human right to access the internet is not established under international human rights law (Tully, 2014; Land, 2013). Rather, a negative state obligation (not to interfere with the means of communication, nor the content) is established as part of

\footnotetext{
${ }^{29}$ See www.internet.org

30 Zuckerberg, Mark (August 20, 2013). "Is Connectivity a Human Right?", available at: https://www.facebook.com/isconnectivityahumanright/isconnectivityahumanright.pdf ${ }^{31}$ NGOs "Open Letter to Mark Zuckerberg Regarding internet.org, Net Neutrality, Privacy and Security". May 18, 2015. Available on many signatories websites, e.g. at: https://cippic.ca/uploads/LT_Facebook_re_internet_org-20150518.pdf 32 See

https://cippic.ca/en/news/facebooks_internet_dot_org_has_too_many_strings_attached ${ }^{33}$ See Facebook announcement at : http://newsroom.fb.com/news/2015/09/update-to-internet-org-free-basic-services/

${ }^{34}$ See http://www.google.com/loon
} 
freedom of expression (Hopkins, 2010; See also ECHR case-law). For example, critique of government interference with individuals internet access routinely features in State Party reports, Concluding Observations and General Comments emanating from the UN human rights committees (see the many examples highlighted in Tully 2014). Also, as argued by La Rue and others giving effect to the right to freedom of expression imposes a positive obligation upon States to promote and facilitate universal internet access $^{35}$. In this sense, the human rights framework may help rectify deficient internet access and ensure greater equality for deprived groups, thus using the moral authority of the human rights discourse to commit states to prioritize this area (Tully, 2014: p. 189).

Arguably, internet access is an enabler for most - if not all - human rights, and thereby relates to societal participation in the broadest sense. Individuals access the internet for multiple purposes, including education, healthcare, community services, commerce and entertainment. As such, internet access has a range of political, economic, social and cultural dimensions. Moreover, its importance in relation to a number of existing rights has been widely recognized by the UN human rights system. In contrast, the call for a new human right to access the internet seems unlikely to succeed. The fundamental rights that make up international human right law was formulated and agreed upon at a specific point in time (post second world war), and many commentators have warned that if those rights were to be renegotiated in the political climate of today, they would be weakened rather than strengthened. Moreover, since the importance of internet access and internet freedoms increasingly is recognized and accommodated as part of existing freedoms and rights related to opinion, expression, privacy, association, cultural participation, etc., the real challenge seems rather to be the effective realization of these rights. In consequence, as access becomes more widespread, the debate may turn back to the themes raised by the proponents of the right to communicate, such as whether or not the internet is enabling a more diverse and decentralized public debate and participation.

Also, one should be cautious by industry attempts to use the global inequality to promote platform-specific internet access as exemplified

\footnotetext{
35 Joint Declaration on Freedom of Expression and the internet by the UN Special Rapporteur on Freedom of Opinion and Expression, the OSCE Representative on Freedom of the Media, the OAS Special Rapporteur on Freedom of Expression and the ACHPR Special Rapporteur on Freedom of Expression and Access to Information, 1 June 2011, at para 6. Available (inter alia) at:

http://www.oas.org/en/iachr/expression/showarticle.asp?artID=849
} 
above, for instance by the internet.org project. Rather than promoting human rights such initiatives may lead to disempowerment and capture of said communities into specific platforms of content, as opposed to an open internet. Moreover, the US Government announced in late September 2015 to the UN General Assembly its Global Connect Initiative ${ }^{36}$. In a nutshell, the initiative consists in making internet access a top priority of all US aid and development agencies worldwide operations, and of engaging international development banks to adopt the same objective. Most notably, the USG statement explicitly mentioned that it "will work with private industry which has created innovative solutions to connect people in remote areas". The implications of these private initiatives and public-private partnerships, including how these developments may change the culture of human rights from a zone of contestation ("power regulator") to a realm of industry-driven Corporate Social Responsibility (CSR) initiatives, may have significant consequences in the long run. The corporate framing of human rights may impact not only on specific rights such as freedom of expression and information, but may have a broader impact on the effective protection of these rights in the online realm.

\section{Introducing a Conflict of Rights: To Be Or Not To Be Forgotten?}

The "right to be forgotten" (RtBF) (or "right to oblivion" as it is sometimes referred to) has been one of the most contentious and debated human rights issues in the past five years, dividing proponents of online privacy and freedom of expression, respectively. Although this controversy was initiated in and largely concerns Europe (and, to the extent that it concerns Google, an American company, the US), we include it in this paper for three reasons: first, other regions of the world have shown considerable interest in this debate (for instance through workshops at the IGF or at some of the regional or national internet governance fora); second, it perfectly illustrates one of the consequences of introducing new rights: that of creating a hard to resolve and quasi-systematic conflicts of rights; third, its unfolding are likely to inform future discussions on the regulation of all sorts of internet platforms operating globally in various sectors (from social networks to the so-called "Uberised" or "sharing" economy and society). This carries many still unresolved challenges for policy decisions, all being highly sensitive in terms of sovereignty and other political, legal, economic, social, cultural and societal choices. One of these main crosscutting challenges is the need to channel and maintain good governance values, including the respect of human rights and social justice, as well as democracy and the rule of law. This is a particularly difficult to address

\footnotetext{
${ }^{36}$ See the USG announcement at : http://www.state.gov/r/pa/prs/ps/2015/09/247374.htm
} 
challenge, with private US firms, such as the GAFA (Google, Apple, Facebook and Amazon) and other giants, dominating the internet market.

In the following, we will thus outline and discuss some of the key moments in the RtBF debate, focusing in particular on the way it challenges human rights standards and the rule of law.

The framing of a right to be forgotten started in Brussels amongst European policy makers and attached experts around 2009 with the publication of Viktor Mayer-Schönberger's book "Delete - The Virtue of Forgetting in the Digital Age" (2009). In January 2012, the European Commission published the Proposal for a Regulation on the Protection of Individuals with Regard to the Processing of Personal Data and on the Free Movement of Such Data ("GDPR"), which updates the current Data Protection Directive from 1995 (95/46/EC). The GDPR is expected to enter into force in 2016, and will instantly become law throughout the European Union. The GDPR has been widely interpreted as to provide all European Union citizens a "right to be forgotten", by giving the individual a right to have his or her personal data removed from the web. This interpretation is based on Article 17 of the initial GPDR proposal ${ }^{37}$ providing for a right for data subjects to request erasure of their personal data as well as the abstention from further dissemination. Article 17 establishes the criteria for when a data subject can have personal data removed, data controllers' obligation to erase links to third-party websites, and how to exercise that right. While this initially proposed Article 17 is explicitly entitled "Right to be forgotten and to erasure", the extent to which it actually provides for a new right and corresponding duties has been contested amongst activists, scholars and regulators. As stressed by van Hoboken (2014), when examining the EC proposal for the data protection reform from January 2012, arguably, there is no such thing as a new right to get data deleted in the proposed Article 17: "The proposal adds a lot of text but doesn't add that much substantively in comparison to the current DPD framework. The situations in which erasure or the abstention of further dissemination of personal data would have to be granted by the controller depend on the rules of the legitimate grounds for processing and the interpretation of rules on purpose limitation. If the basic principles for the fair and lawful processing of

\footnotetext{
37 See EC Communication COM(2012)11 of 25 January 2012 on a "Proposal for a REGULATION OF THE EUROPEAN PARLIAMENT AND OF THE COUNCIL

on the protection of individuals with regard to the processing of personal data and on the free movement of such data (General Data Protection Regulation)", available at: http://ec.europa.eu/justice/dataprotection/document/review2012/com_2012_11_en.pdf
} 
personal data are not strengthened in the Regulation, there is no ground to speak of an actual new 'right' to be forgotten or erasure" (van Hoboken, 2014).

Later in the process, the European Parliament compromise amendments, adopted in March 2014, removed the 'right to be forgotten' from the text of the Regulation but seem to strengthen the right to erasure in some respects. For instance, the right to have links, copies or replication of data deleted has been more clearly stipulated and has been included in Article 17(1) along with an additional ground to obtain the right to erasure, namely in case of a decision by court or regulatory authority based in the Union $^{38}$.

Since the introduction of the GDPR proposal, the "right to be forgotten" has been subject to intense public debate in Europe as well as in the United States, and concern has been raised as to its negative impact on freedom of expression. Similar to the data protection directive, the GDPR strives to balance privacy and freedom of expression by presenting freedom of expression as a limitation on the right to have personal data erased. According to Article 80(2) of the GDPR proposal, it is up to each member state to determine what to include in the freedom of expression exception after the GDPR enters into force.

On this backdrop, the decision of the Court of Justice of the European Union (CJEU) on Google Spain v. AEPD in May $2014^{39}$ was seen by many commentators as reading a "right to be forgotten" into the currently in force Data Protection Directive. The court's decision recognized the right of a Spanish citizen to have personal data about his insolvency dereferenced so that this information would not appear in response to a search for his name in a search engine. The Court classified Google as a controller of personal data and thereby subject to the Data Protection Directive and responsible for removal of the information.

Google and a large number of scholars and activists have consistently warned that the expansiveness of the right to be forgotten as conceptualized by the CJEU and the EU Commission will violate the right to freedom of expression and contribute to rewrite history on the internet.

\footnotetext{
${ }^{38}$ See the whole procedure steps and documents at http://eurlex.europa.eu/procedure/EN/201286

${ }^{39}$ Case C-131/12, Google Spain SL. v. Agencia Española de Protección de Datos (May 13, 2013), http://curia.europa.eu/juris/document/document.jsf?text=\&docid=152065\& doclang=E
} 
The Google Spain decision led to a flood of reactions in the media, particularly in the United States ${ }^{40}$. In the public debate, the Google Spain Decision has been widely referred to as the right to be forgotten ruling, and its implications for freedom of expression and access to information intensively discussed amongst both industry, regulators, academics and civil society.

Former EC Vice-President Viviane Reding have publicly defended the right to be forgotten, both when introducing the GDPR ${ }^{41}$ and in response to the Google Spain decision ${ }^{42}$; newspapers around the world have stated that in Europe people will now be granted the right to have their data deleted ${ }^{43}$, and it has turned out to be one of the most debated topics in scholarship related to the reform of the European data protection regulation ${ }^{44}$. In his Opinion dated 14 January 2011, the then European Data Protection Supervisor, Peter Hustinx, has stressed that in the online domain economic forces work against the individuals' right to privacy, hence there is a need to strengthen the request for data deletion: "from an economic perspective, it is more costly for a data controller to delete data than to keep them stored. The exercise of the rights of the individual therefore goes against the natural economic trend ${ }^{45}$ ". An EU official involved in the development of the GDPR proposal has stressed that "freedom of expression is not a good argument for not having a right to be forgotten" (Rustad and Kulevska, 2015: p 373). Others have argued that the GDPR and the Google Spain ruling merely updates principles that are already part of the European data protection regime, and does not introduce substantially new rights. Generally speaking, there is strong support for a right to be forgotten in Europe. A European Commission study concluded that seventy-five percent of Europeans favor such a right ${ }^{46}$.

In contrast, the right to be forgotten has been ridiculed and criticized by the

40 Examples are provided in van Hoboken (2014) note 107

${ }^{41}$ See her speech of 22 January 2012 at http://europa.eu/rapid/press-release_SPEECH12-26_da.htm

42 See The Gardian article of 4 June 2014 quoting her at http://www.theguardian.com/technology/2014/jun/04/eu-commissioner-right-to-beforgotten-enforce-copyright-google

${ }^{43}$ Examples are provided in van Hoboken (2014) note 26

${ }^{44}$ Examples are provided in van Hoboken (2014) note 98

45 Quote from article 84 of the Opinion of the Data Protection Supervisor, 14 January

2011. http://www.edps.europa.eu/EDPSWEB/webdav/site/mySite/shared/Document s/Consultation/Opinions/2011/11-01-14_Personal_Data_Protection_EN.pdf

${ }^{46}$ Special Eurobarometer 359, June 2011. Attitudes on Data Protection and Electronic Identity in the European Union. Available at:

http://ec.europa.eu/public_opinion/archives/ebs/ebs_359_en.pdf 
involved industry (Google and other search engines), as well as a wide array of US scholars, academics, and free speech advocates. Commentators have warned that the right to be forgotten will lead to censorship of the internet because individuals can request search engines or websites to erase personal data, which may rewrite history ${ }^{47}$. In a widely cited blog post from March 2011, Peter Fleischer, chief privacy counsel of Google, notes that the right to be forgotten, as discussed in Europe, covers three separate categories, each of which proposes progressively greater threats to free speech $^{48}$. Others argue that if content becomes less searchable on the internet, it will "derogate the role of counter-speech" and "disrupt the natural process of communication" (Larson, 2013). As stated by some scholars, the right to be forgotten should not subordinate freedom of expression because free and open public access enables citizens to discuss and share information about society (Rustad and Kulevska, 2015: p 373).

In response to the ruling, Google have established an Advisory Council on the right to be forgotten, and have held meetings in a number of European cities to raise their concerns. An important part of the critique pertain to the enforcement of the right, stressing that the CJEU ruling provides no guidance as to how data controllers are to determine when data that is the subject of an erasure request is no longer necessary or where there is no legal basis for retaining it. Consequently, the burden falls on the data controller to determine those factors, placing Google and other search engines in the position of gatekeepers that determine which data deletion requests should be granted and which should be denied.

In November 2014, the Article 29 Working Party Guidelines published Guidelines to address this concern ${ }^{49}$. The Guidelines provide recommendations to European Data Protection Authorities on how they should address complaints received by individuals after Google denied them their de-referencing request; On 18 June 2015, the Article 29 Working Party published a first evaluation survey ${ }^{50}$ of such complaints. In its report

\footnotetext{
${ }^{47}$ See for instance David Mitchell's comment published in The Guardian on 5 July 2014. The Right To Be Forgotten Will Turn the internet into a Work of Fiction. Available at: http://www.theguardian.com/commentisfree/2014/jul/06/right-to-be-forgotteninternet-work-of-fiction-david-mitchell-eu-google ${ }^{48}$ See Peter Fleischer's blog post. Foggy Thinking About the Right to Oblivion. 9 March 2011. Available at: http://peterfleischer.blogspot.fr/2011/03/foggy-thinking-aboutright-to-oblivion.html

${ }^{49}$ Available at : http://ec.europa.eu/justice/data-protection/article29/documentation/opinion-recommendation/files/2014/wp225_en.pdf

${ }^{50}$ See http://ec.europa.eu/justice/data-protection/article-29/press-material/pressrelease/art29_press_material/2015/20150618_wp29_press_release_on_delisting.pdf
} 
of February 201551, Google's Advisory Council on the right to be forgotten recommended more transparency, underlining that data controllers should be as transparent as possible by providing anonymized and aggregated statistics as well as the process and criteria used in de-referencing decisions. Beyond the benefits to users that request content removed and the wider public, transparency might help search engines shape implementation guidelines and reveal aspects of the legal framework that require clarification. Another challenge is that the right to delete may vary depending on the EU member state, or between EU and other countries, in case the right to be forgotten will eventually be expanded beyond EU member states. As a matter of fact, a first conflict recently arose between the CNIL (the French Data Protection Authority and current Chair of the Article 29 Data Protection Working Party) and Google. In view of a global extension of the right to be forgotten, the CNIL ordered Google to apply dereferencing on all domain names of the search engine, not only restricting its application to search results available in the European domain ${ }^{52}$. On July 30, Google expressed its disagreement on the CNIL's interpretation of the CJEU ruling, asking it to withdraw its formal notice ${ }^{53}$, arguing against such a "troubling development that risks serious chilling effects on the web". On 21 September 2015, the CNIL rejected ${ }^{54}$ Google's request, which may lead to a financial sanction of a maximum of 150000 euros against the company. Interestingly, Google's arguments to deny the application of the RtBF beyond the French jurisdiction are based on freedom of expression, freedom of information and the competence of jurisdictions, while the CNIL remains consistent with considering Google as a data controller, in line with the CJEU ruling.

In sum, the discourse against the right to be forgotten has primarily been driven by US scholars, free speech activists, Google and other industry actors. The Google Spain ruling has been framed as a threat to freedom of expression while its relationship to existing data protection regulation has largely been ignored in the public debate. This is not to say that the actual implementation of the decision is not problematic. From a rule of law perspective, it places private actors as judges of which content to remove

\footnotetext{
${ }^{51}$ Available at See https://www.google.com/advisorycouncil/

52 See CNIL press release at http://www.cnil.fr/english/news-and-

events/news/article/cnil-orders-google-to-apply-delisting-on-all-domain-names-of-thesearch-engine/

53 See http://googlepolicyeurope.blogspot.fr/2015/07/implementing-european-notglobal-right.html

${ }^{54}$ See http://www.cnil.fr/english/news-and-events/news/article/right-to-delistinggoogle-informal-appeal-rejected/
} 
from the public domain (de- referencing), and which to leave up. This form of privatized law enforcement is part of a more general trend towards "selfregulation", where the private actors in control of the internet's infrastructure and core services are tasked with enforcing public policy, without a public mandate. In practical terms, the task of assessing numerous deletion requests may lead to overbroad implementation, not least from less resourceful search engines. Also, as pointed to by the NGO European Digital Rights ${ }^{55}$, Google and other search engines already remove content, for example, when they enforce the US Digital Millennium Copyright Act - without similar freedom of expression concerns - and Google has even granted a "right to be forgotten" for victims of "revenge porn", without restricting its application to Europe ${ }^{56}$. Yet, the freedom of expression and rule of law concerns related to these practices have not received similar attention in the public debate.

Arguably, the right to have personal data deleted as presented in the GDPR in its present form is indeed bound with limitations that put into perspective the risks for freedom of expression. Yet, one may fear for future developments and the lobbying by some states. One challenge relates to the fuzziness of the notion and the potential expansion of the right. In France, for example, some members of Parliaments insisted to demand that this right be extended to a right to delete content that others have published on one user, especially young users. This would mark a slippery slope towards privatized censorship. If the intention is primarily to extend the data subject rights towards a right to informational self-determination, the Council of Europe approach may be a better way forward - as exemplified with the modernization process of Convention 108, including new provisions to strengthen the rights of the data subject ${ }^{57}$.

One of the main risks with unclear and politicized notions such as the right to be forgotten is that it may lead to a change of paradigm, especially in the current context of big data, data mining, and profiling. In this new paradigm, limits on data collection based on purpose would no longer be the default, nor would the principle of data minimization. Rather, the default would become the collection of large amounts of data, with some provisions as a guarantee for control of their use, to the extent that this control can still be reasonably exercised. Although this may seem like an exaggeration, the right to be forgotten can become the fragile companion, or

\footnotetext{
55 See https://edri.org/forgotten/

${ }^{56}$ See https://edri.org/google-admits-it-was-wrong-on-right-to-be-forgotten/

${ }^{57}$ See

http://www.coe.int/t/dghl/standardsetting/dataprotection/modernisation_fr.asp
} 
the crutch of a "right to collect and use big data". At present, this development is promoted both from the industry that strive on big data, and from experts and some data protection authorities (including inside the EU) that advocate for replacing restrictions on data collection with limitations on data use (Mayer-Schönberger and Cukier, 2013). Such a trend might well undermine the principle of purpose limitation, which is one of the cardinal principles of data protection in Europe.

\section{Conclusion}

When considering some of the broader human rights implications of the proposals and developments outlined here, and despite the differences in character and context of the considered examples, some interrelated tendencies seem to emerge, or to confirm trends previously identified in the literature on self- or co-regulation (Frydman, 2004; Marzouki, 2008).

First, we see a shift in how human rights are envisaged and debated, from the traditional focus on state obligations and state enforcement (hard law) to an increasing involvement and call upon private companies to take a role in the realization of some human rights (e.g. through charity actions, participation in soft law development, and through codes of conducts and other corporate social responsibility initiatives). The human rights language is being used (captured) by a variety of actors to promote specific interests, often with limited reflection on human rights as a set of international legal norms, with inherent zones of conflicts (e.g. protection of individuals against abuse of power, commitments to certain standards in society). This shift in the human rights discourse from state obligations to corporate initiatives seems to reflect the nature of the online environment with private actors in control of core infrastructure and services, yet it is extending and its implications for the protection of individuals is troublesome and have not been subject to sufficient substantial analysis yet.

Second, the post WSIS era has witnessed a regression of the concerns related to socio-economic and development (or collective) rights, and an increasing focus on civil and political rights, particularly freedom of expression and privacy, i.e. individual rights (Brousseau and Marzouki, 2012). As mentioned, the legacy of the Universal Declaration of Human Rights is among others due to its specific place in history and the way it stresses the universality and interrelation between civil, political, social, economic, and cultural rights. Increasingly, different actors "pick up" "their" right of interest, with limited attention to the overall framework and the interdependence between the full architecture of rights. Also, the idea of 
inventing new rights (as with the right to internet access) seems to ignore that Conventions are living instruments, and that their standards are expected to be translated their standards into current situations, taking into account technical and socio-economic developments. .

Considered as a whole, these observations indicate a profound redefinition, in the digital sphere, mainly through procedural transformations of existing legislation and regulation, of the legacy of the Universal Declaration of Human Rights. In future work, we wish to explore in more details the hypothesis that this transformation is closely related to the fact that the internet is governed mainly by private actors, that sometimes conflict with state regulations (e.g. in the field of data protection as analyzed here in the case of the right to be forgotten), but other times converge with them as to the means and methods (e.g. through big data mining, algorithmic regulation), and objectives (e.g. profiling and targeting behaviors).

\section{References}

Brousseau, E., and Marzouki, M. (2012). Old Issues, New Framings, Uncertain Implications. in Governance, Regulation and Powers on the internet (Brousseau, E., Marzouki, M., and Meadel, C., Eds). Cambridge: Cambridge University Press. 368-397.

CRIS Campaign (September 2005). Assessing Communication Rights: A Handbook S. Ó. Siochrú, CRIS Campaign.

Franklin, M. I. (2013). Digital Dilemmas: Power, Resistance, and the internet. Oxford: Oxford University Press.

Frau-Meigs, D. (2012). From NWICO to WSIS 30 years of communication geopolitics : actors and flows, structures and divides. Bristol, UK; Chicago, USA, Intellect.

B. Frydman (2004). Coregulation: A Possible Legal Model for Global Governance. in B. de Schutter \& J. Pas (Eds.), About Globalisation. Views on the Trajectory of Mondialisation. Brussels: VUB Press.

van Hoboken, Joris, The European Approach to Privacy (August 25, 2014). 2014 TPRC Conference Paper. Available at 
SSRN: http://ssrn.com/abstract=2418636 or http://dx.doi.org/10.2139/ss rn.2418636

Hopkins, A. T. (2010-2011). "The Right to be Online: Europe's Recognition of Due Process and Proportionality Requirements in Cases of Individual internet Disconnections' (2010-2011)" Columbia Journal of European Law $557(17)$.

Jørgensen, R. F., Ed. (2006). Human rights in the global information society. Cambridge, Mass., MIT Press.

Jørgensen, R. F. (2013). Framing the net : the internet and human rights. Cheltenham, Edward Elgar Pub. Ltd.

Jørgensen, R. F. and M. Marzouki (2005). Human Rights: The missing link. Visions in Process II. O. Drossou, H. Jensen and H. Qazzaz. Berlin, Heinrich Böll Foundation

Land, M. (2013). "Towards an international law of the internet." Harvard International Law Journal 54(2).

Larson III, R. G. (2013). "Forgetting the First Amendment: How ObscurityBased Privacy and a Right To Be Forgotten Are Incompatible with Free Speech." 18 COMM. L. \& POL'Y 91 18(114).

Marzouki, M. (2008). European internet Policies Between Regulation and Governance : Main Issues with Content Regulation. in Wolfgang Benedek, Veronika Bauer, Matthias C. Kettemann (Eds..), internet Governance and the Information Society. Global Perspectives and European Dimensions. Utrecht: Eleven International Publishing, Utrecht.

Marzouki, M. and R. F. Joergensen (2004). "A Human Rights Assessment of the World Summit on the Information Society." Information Technologies and International Development 1(3): 86-88.

Mayer-Schönberger, V. (2009). Delete: The Virtue of Forgetting in the Digital Age, Princeton University Press.

Mayer-Schönberger, V. and K. Cukier (2013). Big data : a revolution that will transform how we live, work, and think. Boston, Houghton Mifflin Harcourt. 
McKenna, A. (2011). A Human Right to Participate in the Information Society New York, Hampton Press.

Padovani, C., Musiani, F., and Pavan, E. (2010. "Investigating Evolving Discourses on Human Rights in the Digital Age: Emerging Norms and Policy Challenges". International Communication Gazette 72(4-5): 359-378.

Parayil, G. (2005). "The Digital Divide and Increasing Returns:

Contradictions of Informational Capitalism." The Information Society: An International Journal 21(1): 41 - 51.

Pieterse, J. N. (2006). "Digital Capitalism and Development: The Unbearable Lightness of ICT4D." Incommunicado Reader. Amsterdam: Institute of Network Cultures: 11-29.

Pollicino, O. and M. Bassini (2011). Internet Law in the era of transition Law. Florence, European University Institute.

Rustad, M. L. and S. Kulevska (2015). "Reconceptualizing the Right to Be Forgotten to Enable Transatlantic Data Flow." Harvard Journal of Law and Technology 28.

Tully, S. (2014). "A Human Right to Access the internet? Problems and Prospects." Human Rights Law Review 14: 175-195.

Wildermuth, N. (2010). Empowerment: the real challenge of digital inclusion. Digital Content Creation: Creativity, Competence, Critique. K. Schrøder and K. Drotner. New York, Peter Lang: 267-286. 